Vaterlaus, J. M., Jones, R. M., \& Tulane, S. (2015). Perceived differences in knowledge about interactive technology between young adults and their parents. Cyberpsychology: Journal of Psychosocial Research on Cyberspace, 9(4), article 3. doi: 10.5817/CP2015-4-3

\title{
Perceived differences in knowledge about interactive technology between young adults and their parents
}

\author{
J. Mitchell Vaterlaus ${ }^{1}$, Randall M. Jones ${ }^{2}$, Sarah Tulane ${ }^{3}$ \\ ${ }^{1}$ Department of Health and Human Development, Montana State University, Bozeman, Montana, United States \\ 2,3 Family, Consumer, and Human Development, Utah State University, Logan, Utah, United States
}

\begin{abstract}
This study was designed to investigate generational differences in knowledge about interactive technology (i.e., cell phones, social networking, email, video chat) between parents and their young adult children. Parents $(n=555)$ and young adults $(n=604)$ residing in the United States provided information about their knowledge in the use of interactive technology. Young adult children also reported their perceptions of their parents' technological knowledge for the various technologies. Comparisons of young adult self-reported technological knowledge and their parents' own reports of technological knowledge revealed that young adults were perceived to be much more knowledgeable than their parents (by both the young adults and their parents) regardless of the technology medium. The largest differences between parents and their young adult children were associated with newer interactive technologies, with the largest gap between parent and young adult knowledge in the area of social networking. Perceived differences between parents and their young adult children were smaller among the technologies that have been in use longer (such as such as e-mail), and larger among the newer modes of interactive technology (e.g., video chat).
\end{abstract}

Keywords: Digital generation gap, social networking, video chat, cell phones, email, ecological theory, parents

\section{Introduction}

Generational theory postulates that generational cohorts emerge when people are born within a 20 year time period, share a location in history, have common beliefs and behavior, and have a sense membership within the generational group (Strauss \& Howe, 1991). Generational cohorts are proposed to be radically different in values and behaviors because they experienced different events during their formative years (Howe \& Strauss, 2003). Investigating generational differences (i.e., the generation gap) between parents and their adolescent/young adult children generated considerable research attention during the 1960s and 1970s, although, actual differences in beliefs and values between parents and their adolescent children were found to be small or insignificant (Jacobsen, Berry, \& Olson, 1975). However, Acock and Bengtson (1980) proposed that the wrong questions were being asked about generational differences. "Rather than ask, 'To what extent is the generation gap real?' we ask, 'Where is the reality of the generation gap?'" (p. 502). When this question was pursued through research, youth perceptions of parental attitudes (not actual parent attitudes) were surprisingly strong predictors of young adults' selfreported attitudes. Acock and Bengtson (1980) concluded that the generation gap exists when perceived differences exist. 
Technology has become an integral part of contemporary family life (McHale, Dotterer, \& Kim, 2009; Vogl-Bauer, 2003; Wartella \& Jennings, 2001), which has again directed attention to generational differences between parents and youth (Clark, 2009; Livingstone, 2003). The Millennial generation (born between 1980 and 2000; Pew Research Center, 2010), which includes contemporary young adults, is proposed to be unique from the Boomer (born between 1943 and 1960; Coomes \& Debard, 2004) and Generation X (born between 1961 and 1981) cohorts based not only on Millennials' access to technology, but how they have seamlessly integrated technology into their social lives (Pew Research Center, 2010). Further, generational differences in technological skills have been proposed, with Millennials experiencing more proficiency and comfort with technology than previous generations (Prensky, 2001). These generational differences have largely been based on anecdotal evidence and have been perpetuated by popular media, but little empirical support for actual generational differences has emerged in the literature - for a review, see Litt (2013). However, consistent with Acock and Bengtson's (1980) conclusions in their generation gap research, a few qualitative studies identified perceived generational differences in technology skills (i.e., perceived digital generation gap) between parents and their children (Clark, 2009; Livingstone, 2003).

Vogl-Bauer (2003) indicated that it is the job of both researchers and families to understand how technology is influencing family functioning. An important first step in understanding the influence of technology related generation differences in families would be to determine the reality of perceived technological generational differences between parents and their children. During the last five decades technology has undergone dramatic shifts, including the transition from being limited to non-interactive technologies (e.g., television, movies) to providing access to a broad array of interactive technologies (e.g., internet, cell phones). Technology users are no longer limited to viewing media, they can also communicate socially with others across the globe (Courtois, Mechant, De Marez, \& Verleye, 2009). Email, social networking, chat rooms, and video chat (e.g., Skype) provides a means for communication to be instant and in some modalities, face-to-face (Jones, 2009). The current study focused on interactive technologies because they are preferred among young adults (Xenos \& Foot, 2008), parents and youth use interactive technologies (Lenhart, Ling, Campbell, \& Purcell, 2010; Pew Research Center, 2014b; Zickuhr, 2011), and the interactive nature of these technologies may provide more relevant implications for parent-child relationships. The current study was designed to explore perceived generational differences in young adult (18-25 years old) and parent self-reported interactive technology skills.

\section{An Ecological Framework}

Bronfenbrenner (1979) proposed that human development proceeds within a set of concentric ecosystems. The microsystem level encompasses the most frequent interactions (e.g., parents, siblings, peers), day-to-day activities of a developing human, and can include many settings (e.g., school, work, home). Some scholars believe that media and technology have become a part of a youth's microsystem because of the frequency of interaction that occurs with technology on a personal and relational level (McHale et al., 2009). Traditionally, the frequent interactions within an adolescent's microsystem would evolve as he or she made commitments (e.g., work, relationships) and developed autonomy from parents into young adulthood (18-25 years old). However, research indicates that young adults are taking on some adult responsibilities, but many continue to rely on parents and other adults more so than previous generations (Arnett, 2000). Prolonged reliance on parents may involve financial support, living arrangements, and emotional support (Aquilino, 2006). These new culturally accepted changes in societal expectations and values (macrosystem) have likely affected sociohistorical conditions (chronosystem; Bronfenbrenner, 1993).

Within Ecological Systems Theory, the mesosystem level involves the interaction of two microsystems (Bronfenbrenner, 1979). In this study we begin to investigate the mesosystem that includes the young adult-technology microsystem and the parent-young adult microsystem. As technology and media have become part of the young adult microsystem experience, it has become apparent that limited research is available concerning the influence of technology on other relationships formed within the microsystem, such as parent-child relationships. Among the current population of young adults, technology has been a part of their microsystem since birth, whereas their parents have grown into this technological age. If parents and young adults differ in their level of technological knowledge, these differences could potentially influence parent-child interactions. One of the first steps in understanding this dynamic would be to investigate whether young adults and parents perceive differences in their interactive technology knowledge. 


\section{A Perceived Digital Generation Gap}

\section{Moving Beyond the Digital Divide}

McHale and colleagues (2009) contend that a microsystem includes the technology the youth owns, the parent owns, or the youth has access to (e.g., internet at school). Research on technological differences between people has generally focused on accessibility to information technology (Mulligan, 2013). The term digital divide generally refers to the perceived gap between socioeconomic, ethnic, racial, or geographic groups who do not have access to the latest technology and those that do (Compaine, 2001). Recent evidence has shown that the divide in internet accessibility is fairly small between young adults and adults in the United States, with $98 \%$ of $18-29$ year olds online and a smaller number of adults (92\% of $30-49$ year olds; $83 \%$ of $50-64$ year olds; $56 \%$ of adults age 65 or older; Rainie, 2013). The advent of cell phones has also reduced this divide. Nearly $63 \%$ of adults (18 and older) use smart phones to access the internet (Duggan \& Smith, 2013). These statistics indicate that a majority of young adults and adults in the United States have access to interactive technology.

Hargittai (2002) stated that digital divide research has focused on the dichotomy of those who have and those who do not have access to technology, and more research is needed concerning people's ability to use these technologies. The terms second-level digital divide (Hargittai, 2002) and usage divide (van Dijk, 2005) were proposed to describe a divide in people's ability to use technology. Since the focus of this study is on perceived generational differences in the ability to use technology, rather than differences in generational accessibility to technology, the term perceived digital generation gap is used to describe generational differences in perceived/self-reported technology knowledge.

\section{Challenging a Digital Native Status}

In 2001, Prensky introduced the concepts of digital native and digital immigrant to discuss generational differences between technology users. Digital natives, who also meet the Millennial generation criteria of being born after 1980 (Pew Research Center, 2010), referred to the younger generation who grew up with technology and are assumed to adapt quickly to new technology (Prensky, 2001). Researchers have found that the younger generation (children and adolescents) has taken expert roles in their homes-learning to use technology and then teaching their parents (Kolodinsky, Cranwell, \& Rowe, 2004; Livingstone, 2003; Oksman \& Turtianinen, 2004). Digital immigrants are described as individuals from earlier generations who have grown into the technological age and experience a learning curve with new technology (Prensky, 2001). For example, Kelty (2000) identified that adults experience difficulty learning computer skills and Walker, Dworkin and Connell (2011) found that parents experienced increased discomfort with more advanced technological skills (e.g., setting up new technology accounts). The accuracy of the native and immigrant terms have not found much empirical support and have remained largely speculative (Koutropolulos, 2011; Litt, 2013).

Litt (2013) completed a comprehensive review on internet skill differences based on age, education, gender, and experience. No studies in the review had quantitatively investigated technology skill differences between parents and their children. Differences between parents and young adults have been identified in terms of how technology is used. Adults ages 34-45, with the exception of emailing, are more likely than their younger counterparts to utilize non-interactive media online (Zickuhr, 2010). Although some adults participate in interactive internet activities, adolescents and young adults participate more. Young adults have the top internet usage statistics (Pew Research Center, 2014a) and are also recognized as early adopters of instant messaging, social networking, and peer-to-peer file sharing (Xenos \& Foot, 2008). The use of cell phones also differs between the generations. Members of older generations typically use their cell phones only for the basic features (voice-to-voice communication). For example, adults 35 and older typically do not use their cell phones for non-voice functions such as taking pictures and text messaging (Zickuhr, 2011). With the advent of smart phone technology it appears that more adults are using the internet on their mobile devices (Duggan \& Smith, 2013). Youth, however, utilize a wide range of functions on their cell phones including going online, listening to music, and emailing (Lenhart et al., 2010).

A difference in how young adults and parents use technology does not guarantee that there are differences in technological knowledge. Preferences alone may not be indicative of knowledge (Koutropolulos, 2011). Mannheim's (1952) seminal work with generations challenges the simplicity of the terms digital natives and digital immigrants by emphasizing actual generations and generational units. Actual generations refer to the individuals who are the same age and experience events within the same 
socio-cultural-historical period. Mannheim (1952) explained that within the actual generation there are distinguishable groups of individuals who address the common experiences in similar ways-leading to separate generational units. Gumpert and Cathcart (1985) and Bolin and Westlund (2009) expanded Mannheim's (1952) work by introducing the term media generations. The term media generations proposes that people are separated by their media experience rather than by their chronological age. Litt's (2013) review on internet skills provides some support for the media generations concept because studies conducted with adolescents and young adults have found "wide internet skills variation" (p. 621).

Prensky's (2001) digital native and immigrant terms were originally widely accepted, however, after more than ten years, critics have argued that the concepts are flawed because technology existed prior to the birth of so called digital natives, and having access and spending time with technology does not imply proficiency (Bennett, Maton, \& Kervin, 2008; Bullen, Morgan, \& Qayyum, 2011; Hargittai, 2010; Helsper \& Eynon, 2010; Koutropolulos, 2011; Litt, 2013). For example, Hargittai, Fullerton, Menchen-Trevino, and Thomas (2010) found that even though 18- to 19-year-olds $(n=1,060)$ had been connected online for years and spent 15 or more hours online weekly, both digitally savvy and much less knowledgeable participants were identified in the sample through completion of a measure of digital literacy. These results indicate that there are different generational units (Mannheim, 1952) or media generations (Bolin \& Westlund, 2009; Gumpert \& Cathcart, 1985) among young adults within the same chronological age groups. These anomalies have challenged the idea of digital natives, but existing research has not explored generational differences in proficiency with technology between parents and adolescents.

\section{Gender Differences}

As technology has evolved attention has been allocated to gender technology differences (Kimbrough, Guadagno, Muscanell, \& Dill, 2013). Women have traditionally been socialized away from technological fields (Kimbrough et al., 2013) and historically, have been under recognized for their technological accomplishments (van Zoonen, 1992). There is some evidence that there are gender differences in the use of interactive technology (Kimbrough et al., 2013). Women report a higher preference for and more use of text messaging, social networking and video calls when compared to men. Again, preference and use of interactive technology may not imply proficiency (Koutropolulos, 2011). In addition to gender differences in technological preferences, Hargittai and Shafer (2006) indicated that men and women had similar abilities to use online technology when actual skills were investigated. However, women perceived a lower level of online technological skill when compared to their male counterparts. Additional research is needed to understand gender differences in perceived ability to use technology among parents and young adults.

\section{Purpose of the Current Study}

For over a decade, popular media and some scholars have promoted the notion that there are gaps in technology skill between the younger and older generations (Prensky, 2001). To date, these proposed digital generational differences have largely been supported by only anecdotal evidence (see Litt, 2013). Efforts to empirically document perceived generational technology differences are just beginning (Clark, 2009) and this is the first study to quantitatively measure the perceived differences. The purpose of the current study was to further investigate the validity of perceived generational differences (i.e., perceived digital generation gap) that have been hinted at in qualitative research (Clark, 2009; Livingstone, 2003) by quantitatively documenting perceptions across generations (young adults and parents) in self-reported interactive technology knowledge. This is an important first step in order to identify how perceived generational technological differences may affect parent-young adult relationships. The study was guided by the following research questions:

Research Question 1. Are there perceived generational differences in interactive technology skills between young adult self-reported skill and young adult perceptions of their parents' interactive technology skills?

Research Question 2. Are there perceived generational differences in interactive technology skills between young adult self-reported skill and parent self-reported interactive technology skills? 


\section{Methods}

\section{Sample}

This study employed a purposive sampling procedure to recruit participants between the ages of 18-25 years old. College students from nine courses at a western university in the United States were invited to participate in this study. Courses were primarily general education courses $(n=6)$ that included students from a variety of disciplines, class levels, and ages. Of the 1,197 students enrolled in these courses, 802 students completed the survey. Participant age ranged from 18 to 48 . Participants between the ages of 18-25 who reported single marital status were included in the final analyses. Eligible participants included 604 young adults who were predominately female $(n=503)$ and Caucasian $(93 \%)$. The majority of these participants $(72.0 \%)$ were between the ages of 18 and 20 . Approximately $85 \%$ of the participants reported that they were living away from their parents in single student housing. A clear majority indicated that they were raised in homes with two biological parents $(82.3 \%)$.

Among the student participants, 555 of their parents (mothers $n=356$, fathers $n=199$ ) also participated in the study. Parents were predominately Caucasian (mothers $=95.2 \%$, fathers $=96.5 \%$ ) and married ( mothers $=88.0 \%$, fathers $=90.9 \%$ ). The average age for participating mothers was 48 -years-old and participating fathers averaged 50 -years-old. These parents were well-educated: $49 \%$ of the mothers and $25 \%$ of the fathers had attended some college; $39 \%$ and $70 \%$, respectively, had earned a bachelor's or post bachelor's degree.

\section{Procedures}

Course instructors agreed to invite their students to participate in this study in March of 2012. The majority of the nine courses were lower division $(n=6)$ and offered face-to-face instruction $(n=8)$. Students were given extra- or assignment-credit as incentive to increase response rates. The questionnaire was administered online and was hosted on a secure website. Additionally, students received additional course credit if one or both of their parents completed the online survey. Participant consent granted access to the questionnaire. Participants were instructed how to ensure they received credit for participation by the researchers. The surveys took students and parents approximately 20-30 minutes to complete. The overall response rate for young adults, after accounting for students who were enrolled in more than one of the participating courses $(n=26)$, was $68.4 \%$. This response rate compares favorably to average response rate of $34.6 \%$ reported in a meta-analysis of 56 web and internet based surveys (Cook, Heath, \& Thompson, 2000).

\section{Measures}

Interactive technology knowledge. Researchers have used a variety of terms to describe technological skill level (Litt, 2013). For instance, Livingstone (2009) used the term "media literacy" in her work to describe a person's ability to access, evaluate (a person's ability to search content and assess for reliability), create, and communicate with media. Given the focus of this study, we used Livingstone's (2009) concept of media literacy to develop questionnaire items about access, creation, and communication. The survey contains a series of questions about four major interactive technology resources including cell phones, email, social networking, and video chat (e.g., Skype). A total of 53 survey items concerning methods or features used to access, create, and communicate with each of the four technology sources were developed using (a) instruction and "how to" pages from websites (e.g., www.skype.com); (b) existing research concerning the percentage of people who use the different features of the technology sources (see Lenhart et al., 2010); and (c) collaboration with people $(n=20)$ between the ages of 18-25 years old. Some technology features that could potentially be seen as independent interactive technologies were conceptualized as features that were integral to broader technology sources. For example, instant messaging features were seen to be a feature within email, which is consistent with large email providers marketing of these features - "Gmail's not just for emailyou can also communicate with your friends in real time using chat in Gmail!" (www.support.google.com).

Dillman, Smyth, and Christian (2009) reported that longer questionnaires result in lower response rates and unanswered questions, because for participants "one of the biggest costs of responding to survey requests is the time it takes to complete the survey" (p. 26). Considering that young adults were going to be asked to rate their own technology skills, their mother's technology skills, and their father's technology skills we sought to refine the list to increase the likelihood of participant response and decrease the likelihood of unanswered survey items. To begin this process we considered that the majority of parents 
and young adults have access and use interactive technologies (Duggan \& Smith, 2013; Rainie, 2013) and because of this it was determined that the most basic interactive technology skills (e.g., turning on a device; typing in a URL to access an email account) would likely result in few differences between young adults and parents. Supporting this proposition, Walker and colleagues (2011) identified that parents were comfortable with basic interactive technology skills, but became more uncomfortable with more complex skills (e.g., setting up an account).

The 53 items were presented to the twenty 18-25 year olds who contributed to the development of the original list. The young adults were asked to rate their perceptions of the percentage of people in general that could utilize the 53 specific interactive technology features (e.g., 10\% meant few people could accomplish the task and $90 \%$ indicated the ease of the feature). These perceptions were interpreted to create an ease of use estimate for each of the four technology resources. To develop the final questionnaire, a cutoff of $70 \%$ was used to differentiate features or methods of use that require more expertise, eliminating the most basic features used by most users. Secondly, where this study specifically focuses on the interactive nature of these technologies, features that do not contribute to interaction were excluded (e.g., using the alarm feature on a cell phone). With both the $70 \%$ cutoff, and interactive requirement, 25 items were removed, resulting in 28 items for the final measure.

Items were presented in an online survey using a Likert scale ranging from (1) "I don't know" to (5) "I know a lot." For example, participants were asked, "How much do you know about sending a picture message [on a cell phone]?" To answer research questions one and two young adults answered the 28 questions three times to indicate perceptions of their own knowledge for each of the interactive technologies, and their perceptions of their mother's and father's knowledge about each interactive technology source. Also, parents reported their own perceived interactive technology knowledge for each of four modalities.

At first glance, the 28 items that were used to capture the young adults' ratings of their knowledge and abilities to use cell phones, email, social networking, and video chat could conceptually be reduced to four subscales by scoring all seven items within each of the four broad categories. However, we recognized that the skills associated with competence in one of the four categories might transfer to skills and competence in one or more of the other three categories. Hence, we entered all 28 items (student ratings of their own abilities) into an exploratory factor analysis using principle components extraction (forcing vector lengths to one for ease of interpretation), eigenvalues greater than one for factor retention, and orthogonal rotation to optimize the uniqueness of each factor. This procedure identified six, linearly independent constructs that accounted for $74 \%$ of the variance in the original correlation matrix (see Table 1). As shown in Table 1, items associated with two of the four technology resources loaded as expected (cell phones and video chat), but the items for email (basic and advanced) and social networking (general social networking and Twitter) were factored into two constructs for each of these broader categories. Young adult responses for each factor were summed to create six constructs, each associated with different aspects of interactive technology.

Pearson's correlations and reliability coefficients were calculated to establish the psychometric properties for each of the six sub-scales. Pearson's $r$ coefficients were all positive, demonstrating that knowledge in one area of technology is positively related with knowledge about other interactive technologies. For example, knowledge about video chat was most strongly related with knowledge about general social networking $(r=.44)$. Conceptually, this makes sense because social networking and video chat are both relatively new technologies, both address social relations, and both may require more advanced skill than is required to use cell phones and/or email. Twitter and basic email had a positive, but small correlation ( $r$ $=.11)$. Twitter is a specified social networking service that entails a different skill set than email. Cell phone and video chat were also strongly related $(r=.51)$. This correlation also makes sense conceptually because smart phone technology provides a means to access to video chat. Cronbach's alpha coefficients for the six scales ranged from .72 to .98, indicating strong internal consistency for each (see Table 1). When the six scales were created from the parental data, a comparable level of internal consistency was found with Cronbach's alpha coefficients ranging from .73 to .96 for mothers and .78 to .99 for fathers. 
Table 1. Factor Loadings of Young Adults' Self-Reported Interactive Technology Knowledge and Item Reliability.

\begin{tabular}{|c|c|c|c|c|c|c|c|}
\hline \multirow[b]{2}{*}{ Variable } & \multicolumn{6}{|c|}{ Factors } & \multirow{2}{*}{$\begin{array}{l}\text { Cronbach's } \\
\text { Alpha }\end{array}$} \\
\hline & I & II & III & IV & $\mathbf{v}$ & VI & \\
\hline I. Video chat & & & & & & & .98 \\
\hline Answering a call & .93 & .13 & .17 & .04 & .01 & .01 & \\
\hline Making a call & .93 & .15 & .19 & .04 & .01 & .03 & \\
\hline Set online status & .93 & .10 & .15 & .09 & .04 & .01 & \\
\hline Adding contacts & .91 & .11 & .17 & .13 & .02 & .08 & \\
\hline Download Skype & .90 & .14 & .17 & .08 & -.01 & .07 & \\
\hline Add/change picture & .90 & .10 & .15 & .17 & .05 & .10 & \\
\hline Deny a new contact & .90 & .08 & .15 & .17 & .01 & .03 & \\
\hline II. Cell phones & & & & & & & .85 \\
\hline Record a video & .16 & .80 & .15 & .02 & .13 & .05 & \\
\hline Video message & .19 & .77 & .04 & .11 & -.02 & .19 & \\
\hline Take a picture & .04 & .70 & .26 & -.04 & .32 & -.12 & \\
\hline Picture message & .10 & .66 & .31 & -.02 & .43 & -.16 & \\
\hline Set up voicemail & .16 & .59 & .17 & .16 & .16 & .23 & \\
\hline III. General social networking & & & & & & & .84 \\
\hline $\begin{array}{l}\text { Managing privacy } \\
\text { settings }\end{array}$ & .20 & .24 & .81 & -.02 & .08 & -.03 & \\
\hline Using chat features & .18 & .25 & .72 & .13 & .07 & .15 & \\
\hline Blocking a person & .27 & .22 & .70 & .03 & .22 & .20 & \\
\hline IV. Twitter & & & & & & & .96 \\
\hline $\begin{array}{l}\text { Following someone on } \\
\text { Twitter }\end{array}$ & .26 & .04 & .17 & .90 & .02 & .01 & \\
\hline Sending a Tweet & .29 & .07 & .14 & .90 & .04 & .01 & \\
\hline V. Basic email & & & & & & & .85 \\
\hline Saving a contact & .03 & .24 & .12 & .07 & .84 & .18 & \\
\hline Saving an email & .01 & .17 & .16 & .01 & .83 & .29 & \\
\hline VI. Advanced email & & & & & & & .72 \\
\hline $\begin{array}{l}\text { Instant messaging } \\
\text { feature }\end{array}$ & .12 & .10 & .13 & .05 & .23 & .80 & \\
\hline Identifying spam emails & .12 & .07 & .17 & .05 & .40 & .70 & \\
\hline Eigenvalues & 10.61 & 3.85 & 1.97 & 1.63 & 1.51 & 1.05 & \\
\hline $\begin{array}{l}\text { Percent of variance } \\
\text { accounted for }\end{array}$ & 37.91 & 13.76 & 7.05 & 5.81 & 5.41 & 3.75 & \\
\hline
\end{tabular}

\section{Results}

Paired $t$ tests were used to identify perceived and parent-young adult self-reported differences in technology knowledge between young adults and their parents. The paired $t$ tests were calculated separately by young adult gender and parent gender because previous research has identified gender differences in the use of interactive technology (Madden, Lenhart, Duggan, Cortesi, \& Gasser, 2013). In order to prevent missing data from being mistakenly interpreted as lower interactive technology knowledge, participants had to respond to each of the items on the scale to be included in a comparison. Several participants responded to one scale, but not another. Rather than excluding participants from the analysis altogether, a multiple comparisons approach was utilized (resulting in different sample sizes for 
each comparison). Because $48 t$ tests were used in the analyses, alpha inflation was taken into consideration. The formula for determining the nominal alpha level was used, 1-(1-.001) ${ }^{48}$, indicating that an observed alpha level of .001 was in fact .046 after adjusting for multiple comparisons. Cohen's $d$ was also calculated to standardize comparisons of differences across technology resources.

\section{Research Question 1}

The first research question explored potential perceived generational differences between young adult self-reported interactive technology knowledge and young adults' reports of their perceptions of their parents' interactive technology knowledge. Nineteen of the 24 comparisons between young adult perceptions of their own technology knowledge and their perceived parent's technology knowledge were statistically significant, even after deflating alpha to adjust for multiple statistical comparisons (see Table 2 ). In each instance young adults perceived they had more interactive technology knowledge than they attributed to their mothers and fathers. These results support the proposition that young adults perceive generational differences in technology knowledge in their parent-child relationships-young adults perceive they know more.

Similarities in perceived interactive technology knowledge were identified for male and female young adults. Cohen's $d$ was used to identify the largest differences between young adults' self-reports and their perceptions of their parents' technological knowledge. Among male and female young adults, the largest perceived difference in technology knowledge for both their father (males $d=1.59$, females $d=1.82$ ) and mother (males $d=1.90$, females $d=2.26$ ) was in the area of social networking. Although the patterns of perceived knowledge differences were similar for male and female young adults, there were variances in the pattern of these differences for mothers and fathers. The second largest perceived mean difference for mothers was in cell phone knowledge for both male $(d=1.09)$ and female $(d=1.28)$ young adults. A large perceived difference for young adult males and their fathers was also evident in cell phone knowledge $(d=.58)$. This was different for young adult females perceptions of fathers' knowledge-the second largest mean difference for perceptions of fathers was in the area of video chat $(d=.77)$.

In general, the largest perceived differences in technology knowledge between parents and young adults are in the technology resources that have been more recently developed (e.g., social networking, video chat) or in technologies that have evolved rapidly (e.g., cell phones). The smallest perceived differences in technology knowledge between parents and young adults (both male and female) were associated with email. Combined, these findings suggest that there are smaller perceived technology differences in the technologies that have been around for the longest.

\section{Research Question 2}

The second research question sought to identify differences/similarities between young adults' selfreported interactive technology knowledge and parent self-reported technology knowledge. As preliminary step, young adults' perceptions of their parents' interactive technology knowledge and parents self-reports were compared (see Table 3). Both male and female young adults perceived that their fathers knew more about the areas of video chat, cell phones, basic email, and advanced email than their fathers actually reported. Male and female young adults consistently underestimated their mother's technological knowledge in the areas of cell phones, social networking, Twitter, and basic email.

Young adult self-reported interactive technology and parents' self-reported technology knowledge were then compared (see Table 4). The means for each comparison were larger for young adults, indicating greater levels of perceived knowledge than their parents reported for themselves. Similar to the findings for perceptions young adults had concerning their parents and their own knowledge, reported above, the majority of the self-reported young adult and parent comparisons for interactive technology knowledge were statistically significant, especially when these comparisons involved the newer or quickly evolving technology areas (e.g., social networking, cell phones).

Cohen's $d$ was used to standardize differences across the technology scales. The largest difference between young adult males and their mothers was in the area of video chat $(d=1.36)$. The largest difference for young adult females and their mothers was in the area of social networking $(d=2.11)$. The comparison between young adults and their fathers also resulted in large mean difference in the area of social networking for both males $(d=2.11)$, and females $(d=2.15)$. The pattern of mean differences for young adult and parent self-reports of their own technology knowledge followed a similar pattern that was 
identified in research question one. Knowledge about social networking, cell phones, and video chat technology resulted in the largest parent-child differences, whereas smaller parent-child knowledge differences were evident with advanced and basic email technologies.

Table 2. Paired Sample $t$ Tests for Young Adult Self-Reported and Perceived Parent Interactive Technology Knowledge by Gender.

\begin{tabular}{|c|c|c|c|c|c|c|c|}
\hline \multirow[t]{2}{*}{ Variable } & \multicolumn{3}{|c|}{$\begin{array}{l}\text { Young Adult } \\
\text { Perceptions of Their Own } \\
\text { Knowledge }\end{array}$} & \multicolumn{2}{|c|}{$\begin{array}{c}\text { Young Adult } \\
\text { Perceptions of their } \\
\text { Parent's Knowledge }\end{array}$} & \multirow[b]{2}{*}{$t$} & \multirow[b]{2}{*}{$d$} \\
\hline & $n$ & Mean & $S D$ & Mean & $S D$ & & \\
\hline \multicolumn{8}{|c|}{ Male Young Adults and Mothers } \\
\hline Video chat & 63 & 12.30 & 11.46 & 4.92 & 8.70 & $5.43 * * *$ & .725 \\
\hline Cell phones & 69 & 17.09 & 4.46 & 10.78 & 6.85 & $8.24 * * *$ & 1.092 \\
\hline General social networking & 73 & 10.00 & 2.92 & 3.73 & 3.65 & $13.75^{* * *}$ & 1.897 \\
\hline Twitter & 95 & 2.32 & 3.03 & .33 & 1.03 & $6.37^{* * *}$ & .879 \\
\hline Basic email & 72 & 7.38 & 1.53 & 6.06 & 2.77 & $3.74 * * *$ & .590 \\
\hline Advanced email & 71 & 6.14 & 2.27 & 4.63 & 2.93 & $4.20 * * *$ & .576 \\
\hline \multicolumn{8}{|l|}{ Male Young Adults and Fathers } \\
\hline Video chat & 67 & 14.51 & 11.64 & 8.58 & 10.50 & $3.62^{* *}$ & .535 \\
\hline Cell phones & 63 & 17.10 & 4.78 & 13.40 & 7.69 & $3.82 * * *$ & .578 \\
\hline General social networking & 68 & 9.72 & 3.10 & 3.52 & 4.56 & $11.48^{* * *}$ & 1.590 \\
\hline Twitter & 92 & 2.28 & 3.00 & 1.07 & 2.21 & $3.20 * *$ & .459 \\
\hline Basic email & 73 & 7.32 & 1.54 & 6.36 & 2.79 & $2.68^{* *}$ & .426 \\
\hline Advanced email & 74 & 6.27 & 2.11 & 5.34 & 2.83 & $2.58^{*}$ & .373 \\
\hline \multicolumn{8}{|c|}{ Female Young Adults and Mothers } \\
\hline Video chat & 281 & 14.52 & 11.76 & 4.46 & 7.83 & $15.21 * * *$ & 1.007 \\
\hline Cell phones & 309 & 17.89 & 3.18 & 11.64 & 6.12 & $18.20 * * *$ & 1.282 \\
\hline General social networking & 371 & 10.56 & 2.28 & 3.70 & 3.63 & $31.97 * * *$ & 2.263 \\
\hline Twitter & 458 & 1.98 & 2.89 & .46 & 1.49 & $11.64 * * *$ & .662 \\
\hline Basic email & 380 & 7.52 & 1.25 & 6.38 & 2.48 & $8.30 * * *$ & .581 \\
\hline Advanced email & 345 & 5.94 & 2.20 & 4.75 & 2.59 & $7.37^{* * *}$ & .495 \\
\hline \multicolumn{8}{|c|}{ Female Young Adults and Fathers } \\
\hline Video chat & 338 & 16.20 & 11.38 & 7.88 & 10.29 & $12.08 * * *$ & .767 \\
\hline Cell phones & 303 & 18.02 & 3.29 & 14.05 & 7.24 & $9.35 * * *$ & .706 \\
\hline General social networking & 348 & 10.48 & 2.32 & 3.80 & 4.65 & $23.61 * * *$ & 1.818 \\
\hline Twitter & 437 & 2.02 & 2.92 & .87 & 2.13 & $7.53 * * *$ & .450 \\
\hline Basic email & 402 & 7.45 & 1.31 & 6.67 & 2.52 & $5.56 * * *$ & .388 \\
\hline Advanced email & 391 & 6.00 & 2.15 & 5.52 & 2.66 & $2.86 * *$ & .198 \\
\hline
\end{tabular}

Note: ${ }^{*} p<.05,{ }^{* *} p<.01,{ }^{* * *} p<.001$. 
Table 3. Young Adult Perceived Parental Interactive Technology Knowledge and Parent Reported Interactive Technology Knowledge.

\begin{tabular}{|c|c|c|c|c|c|c|}
\hline \multirow[t]{2}{*}{ Variable } & \multicolumn{3}{|c|}{$\begin{array}{l}\text { Young Adult Perceptions of } \\
\text { their Parent's Knowledge }\end{array}$} & \multicolumn{2}{|c|}{$\begin{array}{l}\text { Parent Perceptions of } \\
\text { Their Own Knowledge }\end{array}$} & \multirow[b]{2}{*}{$d$} \\
\hline & $n$ & Mean & $S D$ & Mean & $S D$ & \\
\hline \multicolumn{7}{|c|}{ Male Young Adults and Mothers } \\
\hline Video chat & 28 & 6.61 & 10.10 & 3.29 & 7.23 & .378 \\
\hline Cell phones & 30 & 12.00 & 7.28 & 12.33 & 6.95 & .046 \\
\hline General social networking & 43 & 3.81 & 3.80 & 5.05 & 4.58 & .295 \\
\hline Twitter & 55 & .29 & .98 & .85 & 2.21 & .378 \\
\hline Basic email & 49 & 6.10 & 2.63 & 6.45 & 2.33 & .141 \\
\hline Advanced email & 41 & 4.39 & 2.78 & 4.61 & 2.79 & .079 \\
\hline \multicolumn{7}{|l|}{ Male Young Adults and Fathers } \\
\hline Video chat & 19 & 10.32 & 11.66 & 5.26 & 9.51 & .476 \\
\hline Cell phones & 20 & 15.65 & 6.40 & 11.70 & 5.66 & .654 \\
\hline General social networking & 24 & 4.75 & 4.47 & 4.08 & 4.21 & .154 \\
\hline Twitter & 29 & 1.52 & 2.44 & .62 & 1.42 & .451 \\
\hline Basic email & 28 & 7.29 & 1.67 & 6.82 & 2.09 & .249 \\
\hline Advanced email & 28 & 6.43 & 2.17 & 5.04 & 2.36 & .613 \\
\hline \multicolumn{7}{|c|}{ Female Young Adults and Mothers } \\
\hline Video chat & 122 & 4.87 & 8.31 & 3.73 & 7.68 & .142 \\
\hline Cell phones & 146 & 12.18 & 6.02 & 12.51 & 6.59 & .005 \\
\hline General social networking & 204 & 3.57 & 3.64 & 3.83 & 4.03 & .068 \\
\hline Twitter & 267 & .42 & 1.38 & .48 & 1.40 & .043 \\
\hline Basic email & 216 & 6.41 & 2.44 & 6.63 & 2.30 & .093 \\
\hline Advanced email & 194 & 4.84 & 2.57 & 4.64 & 2.68 & .076 \\
\hline \multicolumn{7}{|c|}{ Female Young Adults and Fathers } \\
\hline Video chat & 99 & 7.88 & 10.47 & 5.37 & 8.91 & .258 \\
\hline Cell phones & 82 & 13.93 & 7.44 & 12.41 & 6.40 & .069 \\
\hline General social networking & 111 & 3.85 & 4.60 & 3.91 & 4.33 & .013 \\
\hline Twitter & 147 & .74 & 1.97 & 1.05 & 2.16 & .150 \\
\hline Basic email & 132 & 6.82 & 2.37 & 6.37 & 2.44 & .187 \\
\hline Advanced email & 99 & 7.88 & 10.47 & 5.37 & 8.91 & .258 \\
\hline
\end{tabular}


Table 4. Paired Sample $t$ Tests for Young Adults Self-Reported and Parent Self-Reported Interactive Technology Knowledge by Gender.

\begin{tabular}{|c|c|c|c|c|c|c|c|}
\hline \multirow[t]{2}{*}{ Variable } & \multicolumn{3}{|c|}{$\begin{array}{c}\text { Young Adult } \\
\text { Perceptions of Their Own } \\
\text { Knowledge }\end{array}$} & \multicolumn{2}{|c|}{$\begin{array}{c}\text { Parent } \\
\text { Perceptions of Their } \\
\text { Own Knowledge }\end{array}$} & \multirow[b]{2}{*}{$t$} & \multirow[b]{2}{*}{$d$} \\
\hline & $n$ & Mean & $S D$ & Mean & $S D$ & & \\
\hline \multicolumn{8}{|c|}{ Male Young Adults and Mothers } \\
\hline Video chat & 36 & 15.47 & 11.91 & 2.44 & 6.43 & $5.63 * * *$ & 1.361 \\
\hline Cell phones & 45 & 17.27 & 4.65 & 12.18 & 6.55 & $4.63 * * *$ & .896 \\
\hline General social networking & 39 & 9.85 & 3.41 & 5.12 & 4.73 & $5.23 * * *$ & 1.147 \\
\hline Twitter & 57 & 2.00 & 2.92 & .82 & 2.18 & $2.42 *$ & .458 \\
\hline Basic email & 43 & 7.40 & 1.61 & 6.40 & 2.42 & $2.15^{*}$ & .487 \\
\hline Advanced email & 36 & 6.28 & 2.46 & 4.08 & 2.87 & $3.20 * *$ & .823 \\
\hline \multicolumn{8}{|c|}{ Male Young Adults and Fathers } \\
\hline Video chat & 20 & 18.55 & 11.81 & 6.20 & 10.16 & $2.99 * *$ & 1.121 \\
\hline Cell phones & 28 & 17.50 & 4.03 & 12.46 & 5.60 & $4.24 * * *$ & 1.033 \\
\hline General social networking & 21 & 10.90 & 1.44 & 4.28 & 4.19 & $8.06 * * *$ & 2.113 \\
\hline Twitter & 30 & 2.97 & 3.02 & .60 & 1.40 & $4.17^{* * *}$ & 1.007 \\
\hline Basic email & 22 & 7.45 & 1.26 & 7.05 & 1.65 & 0.83 & .272 \\
\hline Advanced email & 23 & 6.52 & 1.88 & 5.08 & 2.33 & $2.22 *$ & .680 \\
\hline \multicolumn{8}{|c|}{ Female Young Adults and Mothers } \\
\hline Video chat & 150 & 17.31 & 11.00 & 4.45 & 8.22 & $11.22 * * *$ & 1.324 \\
\hline Cell phones & 229 & 18.10 & 2.66 & 13.12 & 6.38 & $10.53 * * *$ & 1.019 \\
\hline General social networking & 215 & 10.58 & 2.17 & 3.75 & 4.04 & $22.41 * * *$ & 2.106 \\
\hline Twitter & 262 & 1.94 & 2.90 & .51 & 1.44 & $6.86 * * *$ & .625 \\
\hline Basic email & 218 & 7.43 & 1.31 & 6.73 & 2.23 & $4.00 * * *$ & .383 \\
\hline Advanced email & 215 & 5.90 & 2.68 & 4.72 & 2.68 & $4.85 * * *$ & .440 \\
\hline \multicolumn{8}{|c|}{ Female Young Adults and Fathers } \\
\hline Video chat & 93 & 17.00 & 10.50 & 6.35 & 9.46 & $6.94 * * *$ & 1.066 \\
\hline Cell phones & 133 & 17.91 & 3.20 & 12.21 & 6.34 & $6.92 * * *$ & 1.135 \\
\hline General social networking & 124 & 10.93 & 1.49 & 4.00 & 4.30 & $17.04^{* * *}$ & 2.154 \\
\hline Twitter & 153 & 1.97 & 2.84 & 1.00 & 2.12 & $3.39 * * *$ & .387 \\
\hline Basic email & 130 & 7.62 & 1.05 & 6.52 & 2.38 & $4.62 * * *$ & .598 \\
\hline Advanced email & 119 & 5.84 & 2.10 & 4.68 & 2.51 & $3.29 * * *$ & .501 \\
\hline
\end{tabular}

Note: ${ }^{*} p<.05,{ }^{* *} p<.01,{ }^{* * *} p<.001$.

\section{Discussion}

Generational differences observed in previous decades have been used to explain observable social, behavioral, and attitudinal discrepancies between parents and their children (Jacobsen et al., 1975). Interest in generational differences has resurfaced with new developments in technology (Clark, 2009) and as technology has become an integral part of the young adult microsystem (McHale et al., 2009). The current exploratory study used Acock and Bengtson (1980) proposition to identify "Where is the reality of the generation gap" (p. 502)-identifying both perceived digital generational differences (comparisons of young adults' self-reported knowledge and their perceptions of their parent's knowledge) and parentyoung adult self-reported knowledge differences. To our knowledge, this is the first study that has 
documented perceived digital generational differences by collecting perceptions from both generations (i.e., young adults and parents). Results indicate that perceived differences in interactive technology knowledge do exist between young adults and their parents.

\section{Perceived Digital Generation Gaps}

The Millennial generation (born between 1980 and 2000) has been distinguished from previous generations because of their seamless integration of technology into their lives. This proposition has been supported and become widespread with Prensky's (2001) introduction of the terms of digital native and digital immigrant-highlighting that Millennials easily adapt to new technology, while their parents experience difficulty. The critics of Prensky's (2001) digital native and immigrant terms have used media literacy differences amongst one generation (same-aged peers) to discount the terms' validity (see Koutropolulos, 2011). It may be that there are media generations (Gumpert \& Cathcart, 1985) or generational units (Mannheim, 1952) within same-aged groups, but our results demonstrate differences in perceived technological knowledge between the two generations. Until now, the perceived digital generation gap has not been documented quantitatively using data from both children and their parents. Using Acock and Bengtson's (1980) proposition to identify where generation gaps are real proved fruitful, and quantitative results in the current study confirm the existence of perceived generational technology differences previously alluded to from qualitative studies (Clark, 2009).

In this study, young adults rated their own knowledge higher than their perceptions of their parents' knowledge in six different areas of interactive technology knowledge. Results also indicated that the young adult participants in this study did not perceive that their parents had no knowledge of these technologies, but they did indicate that they knew more than their parents did. This phenomenon was observed for all six of the technology modalities investigated in this study, including newer and older interactive technologies, and when examined separately by gender. The current study relied on selfreported (estimates) of knowledge and did not assess actual abilities. Although perceived generational differences were documented, it still remains unclear if there is an actual (objective) generational gap in interactive technology knowledge.

\section{Gender and Perceived Parental Technology Knowledge}

It was interesting to note that young adults over-estimated their father's knowledge and they underestimated their mother's knowledge of interactive technology. Women have traditionally been socialized away from careers and education in fields where technology is imperative, which could result in less access to interactive technology (Kimbrough et al., 2013). These ideas are challenged with current data about interactive technology ownership and usage. For example, a similar number of adult men $(80 \%)$ and women (82\%) report using the internet (Pew Research Center, 2013), male and female adults have the same percentage of cell phone ownership (92\% of men, $92 \%$ of women; Anderson, 2015), and more adult women $(71 \%)$ use social networking sites than adult men (62\%; Duggan \& Brenner, 2013). Perhaps usage does not imply proficiency with technology (Koutropolulos, 2011).

Hargittai and Shafer (2006) found that women tend to underestimate their own ability to use online technology, but men and women had similar actual ability to use technology. It is presently unclear as to why there is a gendered discrepancy in terms of young adult's perceptions of parental technology knowledge. There may be socially constructed gender differences in technological ability. These gender differences may also be indicative of stereotypes (i.e., shared generalized beliefs of a group of people that are used to explain behavior; McGarty, Yzerbyt, \& Spears, 2002) about mothers' ability to use technology. Expecting less technological knowledge and skill from women may decrease their perceptions of their own knowledge or steer them away from gaining more technological knowledge, because stereotypes can influence perception and behaviors (McGarty et al., 2002). Regardless of the origins of these gender differences, this finding warrants further exploration in terms of how perceived differences in mother and father technology knowledge influences parent-child interaction. The common adage "knowledge is power" may come into play with unique power differentials in the father-child and mother-child dyads.

\section{Perceived Digital Generation Gaps: New versus Established Technology}

The identified perceived technological generation differences followed a trend with the smallest differences evidenced in technologies that have been around for the longest time. From a generational perspective this makes intuitive sense because adults have had more opportunity to learn and adapt to technologies 
with which they have had more contact. The largest perceived generational technology differences were associated with more recent interactive technologies or with technologies that have evolved rapidly. In general, the largest differences (in results for both research questions) were found in the areas of social networking, video chat, and cell phones. Smaller differences were found in the email categories (basic and advanced).

Social networking and video chat are relatively new technologies. For example, Facebook, the most frequently used social networking site (Duggan, Elisson, Lampe, Lenhart, \& Madden, 2015), was launched in 2004 and released for complete access to the general public in 2006 (boyd \& Ellison, 2007). Skype (the most popular medium of video chat) was made available in 2003 (Ehlert, Petgang, Magedanz, \& Sisalem, 2006). In contrast, cell phone technology has been around for over 25 years (Zheng \& Ni, 2006), which would imply that most parents have had some exposure to cell phones. However, people over the age of 35 typically utilize cell phone technology for talking and they typically do not use their cell phones for non-voice functions (Zichuhr, 2010). The results of this study show that parents have some self-reported knowledge of social networking, video chat and cell phones, but significantly less knowledge than do their young adult children. Kelty (2000) indicated that adults have more difficulty adapting to new computer technology and Walker and colleagues (2011) reported that parents experience discomfort with more advanced technological skills. The newer advances in each of these interactive technologies where perceived gaps were identified may be challenging for parents.

On the other hand, email technology has been around for some time. By 1995 email technology was made publicly available (Partridge, 2008). Also, Zichuhr (2010) indicated that email is the most frequent interactive technology used by adults between the ages of 35-45. The length of time and experience that parents have had with email may account for young adults' smaller perceived differences.

\section{Technology-Young Adult and Parent-Young Adult Mesosystem}

The young adult microsystem appears to have evolved with changes in societal expectations for young adults (Arnett, 2000) and with advances and accessibility to technology. McHale and colleagues (2009) indicated that along with parents, siblings, and peers, technology is now a part of the enduring and frequent interactions within a youth's microsystem. Parents, siblings, and peers can be young adults' companions in media or models for media use. Results from this study revealed that perceived digital generation differences are present in the parent-young adult microsystem, thus providing support for previous propositions about generational technology differences that have been disseminated publicly, largely without empirical support (Litt, 2013). In this instance, generalized beliefs and perceptions about parent and young adult technology knowledge could influence parent and young adult behavior and perceptions. It is very possible that these technological differences could influence parent-young adult relational dynamics (e.g., conflict, parental-knowledge, quality time) and a parent's ability to be a media companion and model.

Perceived differences in the purposes of technology have been identified to lead to parent-child conflict. For example, Mesch (2006) reported that adolescents perceive parent-child conflict when adolescents used the internet for social purposes (e.g., connecting with friends), but not when they used the internet for completing homework. It may be the perceived digital knowledge differences are also related to parent-child conflict. Additionally, parents that know how to use technology and a full range of features have a better chance at using technology to connect with their children. This would be especially important in maintaining parent-child relationships during young adulthood when many children move away from home for work or to attend college.

Finally, digital generational differences may impede the process of parental mediation (i.e., monitoring media of technology; Vaterlaus, Beckert, Tulane, \& Bird, 2014). Young adults and parents reported that a lack of parental technological knowledge was a reason parents do not mediate their young adult's technology use (Vaterlaus, Beckert, \& Bird, 2015). Mediating new technology can be difficult because many of the devices are designed for private use. Replicating these digital generation gap results with adolescents (12-18 years old) and investigating the influence on parental mediation would be an especially important step for future research. 


\section{Limitations and Recommendations}

This study was conducted to identify perceived differences in knowledge associated with interactive technology between young adults and their parents. The purposive sampling procedure used in this study was an appropriate first step to document the existence of perceived generational differences in interactive technology knowledge, but does limit the generalizability of the findings in this study. The participants (both parents and young adults) in this study were quite homogenous and results should be replicated with parent-adolescent and parent-young adult dyads from multiple ethnicities, age groups, and socioeconomic statuses. Also, in this study perceptions of technological knowledge were measured, rather than actual technological knowledge. A measurement of actual technological knowledge would be helpful in furthering our understanding on the topic (e.g., people completing the tasks on a cell phone or computer in a laboratory setting). Further, the current study focused solely on perceptions of intergenerational technological knowledge differences.

Gumpert and Cathcart (1985) purported that people are separated more by their media experience rather than by their chronological age. Investigating differences in both media literacy (the ability to use and process interactive media) and media grammars (the rules and conventions associated with specific media; Gumpert \& Cathcart, 1985) would provide a more in-depth description of intergenerational differences in media experience.

It is recommended that future research include measure of both perceived and actual differences in technology knowledge. Acock and Bengtson (1980), in their work on actual versus perceived differences in parent-child relationships, found that adolescent perceptions of parents' opinions had a more direct effect on adolescents' attitudes than actual parent opinions. Collecting actual and perceived differences may lead to a more complete understanding of the potential effect of digital knowledge differences on parent-child relational outcomes. Additionally, investigating the influence of the magnitude (e.g., small versus large) of these technology knowledge differences on parent-child relationships would be vital.

Considering the rapidity of the development and evolution of technology, it is suggested that future research use a longitudinal approaches to better understand how advances in technology are incorporated by parents and their children and to examine differences in the acquisition of knowledge over time. In general, digital generation gaps were largest among the newest technologies and smallest among technologies that have been available for some time. A longitudinal design would provide an opportunity to further explore this pattern and identify changes/maintenance of technology knowledge for parents and their children.

\section{References}

Acock, A. C., \& Bengtson, V. L. (1980). Socialization and attribution processes: Actual versus perceived similarity among parents and youth. Journal of Marriage and Family, 42, 501-515.

http://dx.doi.org/10.2307/351895

Anderson, M. (2015). The demographics of device ownership. Retrieved from

http://www.pewinternet.org/2015/10/29/the-demographics-of-device-ownership/

Aquilino, W. S. (2006). Family relationships and support systems in emerging adulthood. In J. J. Arnett \& J. L. Tanner (Eds), Emerging adults in America (pp. 193-218). Washington, DC: American Psychological Association.

Arnett, J. J. (2000). Emerging adulthood: A theory of development from the late teens through the twenties. American Psychologist, 55, 469-480.

Bennett, S., Maton, K., \& Kervin, L. (2008). The 'digital natives' debate: A critical review of the evidence. British Journal of Educational Technology, 39, 775-786. http://dx.doi.org/10.1111/j.14678535.2007.00793.x

Bolin, G., \& Westlund, O. (2009). Mobile generations: The role of mobile technology in the shaping of Swedish media generations. International Journal of Communication, 3, 108-124. 
boyd, d. m., \& Ellison, N. B. (2007). Social network sites: Definition, history, and scholarship. Journal of Computer-Mediated Communication, 13, 210-230. http://dx.doi.org/10.1111/j.1083-6101.2007.00393.x

Bronfenbrenner, U. (1979). The ecology of human development. Cambridge, MA: Harvard University Press.

Bronfenbrenner, U. (1993). Ecological models of human development. In M. Gauvain \& M. Cole (Eds.), Readings on the development of children (2nd ed.) (pp. 37-43). New York: Freeman.

Bullen, M., Morgan, T., \& Qayyum, A. (2011). Digital learners in higher education: Generation is not the issue. Canadian Journal of Learning and Technology, 37. Retrieved from

http://cjlt.csj.ualberta.ca/index.php/cjlt/article/view/550

Clark, L. S. (2009). Digital media and the generation gap: Qualitative research on US teens and their parents. Information, Communication, \& Society, 12, 388-407.

http://dx.doi.org/10.1080/13691180902823845

Compaine, B. M. (2001). The digital divide: Facing a crisis or creating a myth? Cambridge, MA: MIT Press.

Cook, C., Heath, F., \& Thompson, R. L. (2000). A meta-analysis of response rates in web-or internetbased surveys. Educational and Psychological Measurement, 60, 821-836.

http://dx.doi.org/10.1177/00131640021970934

Coomes, M. D., \& DeBard, R. (2004). A generational approach to understanding students. New Directions for Student Services, 2004(106), 5-16. http://dx.doi.org/10.1002/ss.121

Courtois, C., Mechant, P., De Marez L., \& Verleye, G. (2009). Gratifications and seeding behavior of online adolescents. Journal of Computer-Mediated Communication, 15, 109-137.

http://dx.doi.org/10.1111/j.1083-6101.2009.01496.x

Dillman, D. A., Smyth, J. D., \& Christian, L. M. (2009). Internet, mail, and mixed-mode surveys: The tailored design method. Hoboken, NJ: John Wiley \& Sons.

Duggan, M. \& Brenner, J. (2013). The demographics of social media users, 2012. Retrieved from http://www.pewinternet.org/2013/02/14/the-demographics-of-social-media-users-2012/

Duggan, M., \& Smith, A. (2013). Cell Internet use 2013. Retrieved from

http://www.pewinternet.org/2013/09/16/cell-internet-use-2013/

Duggan, M., Ellison, N. B., Lampe, C., Lenhart, A., \& Madden, M. (2015). Social media update 2014. Retrieved from http://www. pewinternet.org/2015/01/09/social-media-update-2014/

Ehlert, S., Petgang, S ., Magedanz, T., \& Sisalem, D. (2006). Analysis and signature of Skype VoIP session traffic. Fraunhofer FOKUS Technical Report NGNI-SKYPE-06b. Retrieved from http://www.cs.columbia.edu/ salman/skype/Ehlert_SkypeSignature_2006.pdf

Fox, S. (2013). Pew: Internet health. Pew Internet and American Life Project. Retrieved from http://www.pewinternet.org/Commentary/2011/November/Pew-Internet-Health.aspx

Gumpert, G., \& Cathcart, R. (1985). Media grammars, generations, and media gaps. Critical Studies in Media Communication, 2, 23-35. http://dx.doi.org/10.1080/15295038509360059

Hargittai, E. (2002). Second-level digital divide: Differences in people's online skills. First Monday 7(4). http://dx.doi.org/10.5210/fm.v7i4.942

Hargittai, E. (2010). Digital $\mathrm{Na}(\mathrm{t})$ ives? Variation in internet skills and uses among members of the "Net Generation"*. Sociological Inquiry, 80, 92-113. http://dx.doi.org/10.1111/j.1475-682X.2009.00317.x 
Hargittai, E., \& Shafer, S. (2006). Differences in actual and perceived online skills: The role of gender*. Social Science Quarterly, 87(2), 432-448.

Hargittai, E., Fullerton, L., Menchen-Trevino, E., \& Thomas, K. Y. (2010). Trust online: Young adults' evaluation of web content. International Journal of Communication, 4, 468-494.

Helsper, E. J., \& Eynon, R. (2010). Digital natives: Where is the evidence? British Educational Research Journal, 36, 503-520. http://dx.doi.org/10.1080/01411920902989227

Howe, N., \& Strauss, W. (2003). Millennials go to college. Great Falls, VA.: American Association of Registrars and Admissions Officers and LifeCourse Associates.

Jacobsen, R. B., Berry, K. J., \& Olson, K. F. (1975). An empirical test of the generation gap: A comparative intrafamily study. Journal of Marriage and Family, 37, 841-852.

http://dx.doi.org/10.2307/350836

Jones, S. (2009). Generations online in 2009. Retrieved from

http://pewresearch.org/pubs/1093/generations-online

Kelty, N. (2000). Computer proficiency: The digital generation gap. Research report. Retrieved from http://eric.ed.gov/PDFS/ED471132.pdf

Kimbrough, A. M., Guadagno, R. E., Muscanell, N. L., \& Dill, J. (2013). Gender differences in mediated communication: Women connect more than do men. Computers in Human Behavior, 29, 896-900. http://dx.doi.org/10.1016/j.chb.2012.12.005

Kolodinsky, J., Cranwell, M., \& Rowe, E. (2004). Bridging the generational gap across the digital divide: Teens teaching internet skills to senior citizens. Journal of Extension, 40(3). Retrieved from http://www.joe.org/joe/2002june/rb2.php

Koutropolulos, A. (2011). Digital natives: Ten years after. Journal of online learning and Teaching, 7. Retrieved from http://jolt.merlot.org/vol7no4/koutropoulos_1211.htm

Lenhart, A., Ling, R., Campbell, S., \& Purcell, K. (2010). Teens and mobile phones. Retrieved from http://pewinternet.org/ /media//Files/Reports/2010/PIP-Teens-and-Mobile-2010-with-topline.pdf

Litt, E. (2013). Measuring users' internet skills: A review of past assessments and a look toward the future. New Media \& Society, 15, 612-630. http://dx.doi.org/10.1177/1461444813475424

Livingstone, S. (2003). Children's use of the internet: Reflections on the emerging research agenda. New Media and Society, 5, 147-166. http://dx.doi.org/10.1177/1461444803005002001

Livingstone, S. (2009). Children and the Internet. Cambridge, England: Polity Press.

Madden, M., Lenhart, A., Duggan, M., Cortesi, S., \& Gasser, U. (2013). Teens and technology. Retrieved from http://www.pewinternet.org/Reports/2013/Teens-and-Tech.aspx

Mannheim, K. (1952). The problem of generation. In Essays on the Sociology of Knowledge (pp 276-320). London: Routledge.

McGarty, G., Yzerbyt, V. Y., \& Spears, R. (2002). Social, cultural and cognitive factors in stereotype formation. In C. McGarty, V. Y. Yzerbyt, \& R. Spears (Eds.), Stereotypes as explanations (pp. 1-15). New York, NY: Cambridge University Press.

McHale, S. M., Dotterer, A. \& Kim, J. (2009). An ecological perspective on the media and youth development. American Behavioral Scientist 52, 1186-1203.

http://dx.doi.org/10.1177/0002764209331541 
Mesch, G. S. (2006). Family characteristics and intergenerational conflicts over the internet. Information, Communication, and Society, 9, 473-495. http://dx.doi.org/10.1080/13691180600858705

Mulligan, M. (2013). Data and deficits-towards a more truthful account of the digital divide. Journal of International Affairs, 102, 91-92.

Oksman, V., \& Turtiainen, J. (2004). Mobile communication as a social stage: Meanings of mobile communication in everyday life among teenagers in Finland. New Media and Society, 6, 319-339. http://dx.doi.org/10.1177/1461444804042518

Partridge, C. (2008), The history of internet email. Annals of the History of Computing, 30, 2-29.

Pew Research Center (2010). Millennials: A portrait of generation next. Retrieved from http://www.pewsocialtrends.org/files/2010/10/millennials-confident-connected-open-to-change.pdf

Pew Research Center (2013). Trend data (adults). Retrieved from http://www.pewinternet.org/StaticPages/Trend-Data-(Adults)/Whos-Online.aspx

Pew Research Center (2014a). Internet user demographics. Retrieved from http://www. pewinternet.org/data-trend/internet-use/latest-stats/

Pew Research Center (2014b). Social networking fact sheet. Retrieved from http://www.pewinternet.org/fact-sheets/social-networking-fact-sheet/

Prensky, M. (2001). Digital natives, digital immigrants, part II: Do they really think differently? On the Horizon, 9, 1-6. Retrieved from http://www.marcprensky.com/writing/Prensky\%20-

\%20Digital\%20Natives,\%20Digital\%20Immigrants\%20-\%20Part2.pdf

Rainie, L. (2013). Internet adoption becomes nearly universal among some groups, but others lag behind. Retrieved from http://www.pewresearch.org/fact-tank/2013/05/30/internet-adoption-becomes-nearlyuniversal-among-some-groups-but-others-lag-behind/

Strauss, W., \& Howe, N. (1991). Generations: The History of America's Future, 1584 to 2069. New York, NY: Morrow.

van Dijk, J. A. (2005). The deepening divide: Inequality in the information society. Thousand Oaks, CA: Sage.

van Zoonen, L. (1992). Feminist theory and information technology. Media, Culture and Society, 14(1), 929. http://dx.doi.org/10.1177/016344392014001002

Vaterlaus, J. M., Beckert, T. E., \& Bird, C. V. (2015). "At a certain age it's not appropriate to monitor one's child": Perceptions of parental mediation of emerging adult interactive technology use. Emerging Adulthood, 3, 353-358. http://dx.doi.org/10.1177/2167696815581277

Vaterlaus, J. M., Beckert, T. E., Tulane, S., \& Bird, C. V. (2014). "They always ask what I'm doing and who I'm talking to": Parental mediation of adolescent interactive technology use. Marriage and Family Review, 50, 691-713. http://dx.doi.org/10.1080/01494929.2014.938795

Vogl-Bauer, S. (2003). Maintaining family relationships. In D. J. Canary and M. Dainton (Eds.), Maintaining Relationships Through Communication (pp. 31-50). Manwah, NJ: Lawrence Erlbaum Associates.

Walker, S. K., Dworkin, J., \& Connell, J. (2011). Variation in parent use of information and communications technology: Does quantity matter?. Family and Consumer Sciences Research Journal, 40, 106-119. http://dx.doi.org/10.1111/j.1552-3934.2011.02098.x

Wartella, E. \& Jennings, N. (2001). New members of the family: The digital revolution in the home. Journal of Family Communication, 1, 59-69. http://dx.doi.org/10.1207/S15327698JFC0101_07 
Xenos, M., \& Foot, K. (2008). Not your father's internet: The generation gap in online politics. In W. L. Bennett (Ed), Civic life online: Learning how digital media can engage youth (pp. 51-70). Cambridge, MA: The MIT Press.

Zheng, P., \& Ni, L. (2006). Smart phones and next generation mobile commuting. New York: NY: Elsevier.

Zickuhr, K. (2010). Generations. Retrieved from http://pewinternet.org/Reports/2010/ Generations2010.aspx

Zickuhr, K. (2011). Generations and their gadgets. Retrieved from http://pewinternet.org/ /media//Files/Reports/2011/PIP_Generations _and_Gadgets.pdf

\section{Correspondence to:}

J. Mitchell Vaterlaus

Department of Health and Human Development

Montana State University

P.O. Box 173540

Bozeman, MT 59717-3540

Email: j.vaterlaus(at)montana.edu

\section{About authors}

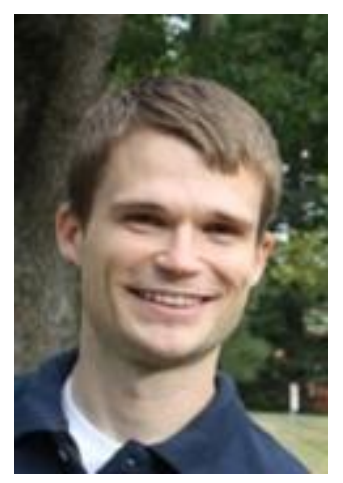

J. Mitchell Vaterlaus, PhD, LMFT is an Assistant Professor in the Department of Health and Human Development at Montana State University. His research interests include applied family science and new media and technology influences on family and human development. Dr. Vaterlaus is particularly interested in the role technology plays in parent-child relationships during adolescence and young adulthood.

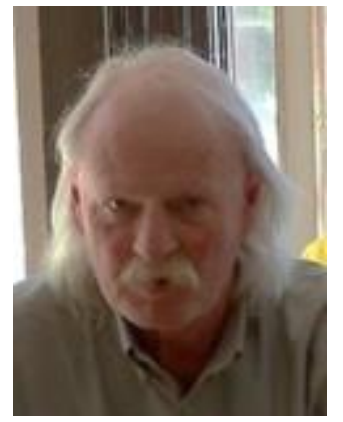

Randall M. Jones, PhD is a Professor and Coordinator of Graduate Programs in the Department of Family, Consumer, and Human Development at Utah State University. His research focus includes: 1 ) identity development and a wide range of adolescent problem behaviors (criminal activity, delinquency, precocious sexual behavior), 2) family, social, and technological influences on identity development, and 3) reciprocal relations between adolescent identity development and adolescent environments (imposed, selected, and constructed). Outside of his work, Jones enjoys spending time with his wife and pets (Norwegian Elkhounds).

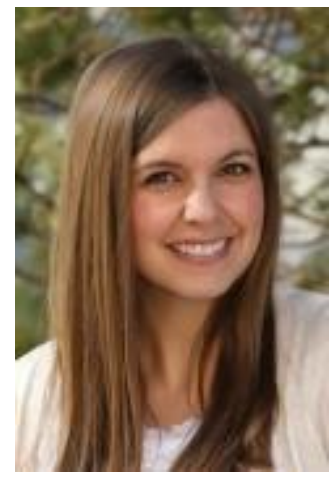

Sarah Tulane, PhD is a Clinical Assistant Professor in the department of Family, Consumer, and Human Development at Utah State University. She received her PhD from Utah State University in Family and Human Development with an emphasis in adolescence. Her research interests include adolescent psychosocial development, technology and relationships, and family life education. 